\title{
Socio - Economic Impact of Remittance on Households in Lekhnath Municipality, Kaski, Nepal
}

\author{
Ananta Raj Dhungana, PhD * \\ Dipendra Pandit**
}

\begin{abstract}
The study aims to explore the impact of remittance on social and economic status at households. For this purpose, one hundred and forty seven households having migrant family member (at least one) were selected in Lekhnath Municipality of Kaski District, Nepal. The information was collected via interview by using structured interview schedule. Descriptive as well as inferential statistics were carried out to analyze the impact of remittance. Paired t-test was carried out to see the economic change before and after the remittance received. The impact of remittances on both economic status and the social status of the sampled households is remarkable. The perceived status of the household in the pastmigration period is better than that in the pre-migration period. Yearly remittance in a household is significantly associated with other socio-economic variables. So, overseas remittance has brought a qualitative change in children's education and health status. An improvement in the economic status of migrant households, the involvement of the household in community development activities, and participation of the household in social organization have brought a positive change in the overall socio-economic status of the migrant households.
\end{abstract}

Key Words: foreign employment, migration, remittance, socio-economic impact, household status.

\section{BACKGROUND}

Migration for less economic developed to developed countries has increased dramatically in recent years, including the South Asian countries, a trend which is predicted to gain strength in the foreseeable future. About 61.64 percent of Nepal's population constitutes the labour force ageed between 15-64 years. According to CBS, 2011 at least one member in every fourth household in Nepal is absent in their birth place. Out of every two (56\%) households in Nepal has a grace of receiving remittance (NLSS-III). Due to the decline in employment opportunities in the country, there is an increasing trend towards the migration of Nepalese workers abroad. Privatization of

\footnotetext{
*Dr. Dhungana is Assistant Professor of Pokhara University, Nepal;

Email: anantastat@gmail.com

**Mr. Pandit is a Masters Research student at Pokhara University
} 
state owned industries, collapse of industrial enterprises, violent conflicts and lack of opportunities in Nepal have been propelling the workers to migrate abroad for livelihood security (Dahal, 2004).

Remittances are commonly defined as that portion of a migrant's earnings sent from the migration destination to the place of origin. The term usually refers to monetary transfer only, although remittances can also be sent in-kind. In most of the literature the term is further limited to transfers sent by migrant workers, but it is worth noting that refugees and other migrants who do not benefit from the legal status of migrant workers also send remittances (Nair, 2009). Workers' remittances are an important source of income and poverty alleviation for migrants, their households and their communities of origin in many parts of the developing world (Arif, 2009). The "new economics of labour migration", a theoretical perspective, views remittance transfers as part of a household decision-making strategy to reduce risk and increase investment opportunities in areas where credit, insurance and capital markets are absent or imperfect (Taylor, 1999). Remittances are increasingly the most direct immediate and significant contribution to the livelihoods of the people. The benefits of remittance are not limited or recipient households but have a wider impact on the receiving society as remittance are spent, generating consumer demand and jobs for local workers. Remittances improve living conditions; education, health in the communities of assign and provide insurance against income shocks. Remittances have been studied to ascertain to what degree these flows serve to develop the migrant sending societies, including the increasing of consumption levels providing for housing promoting business investments and increasing the availability of health and education services for family member.

A study based on survey of 4000 households (UNDP, 2010) gives an idea of expenditure and effects of remittances. In this consideration it is important to know how households use remittance and how they may impact the economy of Kosovo. It was suggested that remittance not only affect positively the level of income, but also the ability to access health care and education. Most of remittances received are used for consumption (45\%) where as 11 percent are used for business investment and 12 percent for housing investment (UNDP, 2010 cited in Alishani and Nushi, 2012).

The major foreign income source to both the households and the government is remittance. It is generally perceived that international migration attributes mostly to home country and countries of destination. Aspects like economic, social and to some extent, political get highly flourished in home countries. Economically, the home countries could reap enormous benefits such as foreign exchange remittance, investment, technology transfer and training for its labor force. Socially, emigration to a developed country brings the cultures of the two relevant societies in greater contact, and the ideas, attitudes, policies and practices that help to foster economic and social development in a tighter bondage. The trend of remittance has had an important implication for the economies seen both in micro and macro perspective. The remittance not only affects positively level of income, but also the ability to access healthcare and education (Alishani and Nushi, 2012). In microeconomic prospective remittances directly affect household income and consumption, whereas in macroeconomic perspective remittances influence poverty reduction (Adams, 2005), economic growth entrepreneurship and financial development (Alishani and Nushi, 2012). But why do Nepali migrants get a very low salary in foreign countries? The households who have high 
remittance are not utilizing it in creative and productive areas. They only invest it for purchasing luxuries.

Remittance, therefore, becomes a relatively more attractive source of foreign earning for developing countries in general and Nepal in particular. It has been widely believed that remittances help to improve health outcome by the means of purchasing better care and nutrition and by increasing health knowledge of the family member. While negative impact is expected as smaller amount of time spent by the parents with their children, which is only a short term effect. In the long-run, remittances bring significant improvement in the child health (Yusufi, 2012). However, little attention has been paid to analyze the social and economic impact of these financial transactions, especially on economic growth and poverty alleviation. This study is, therefore, carried out to explore the socio-economic impact of remittance on households.

\section{DATA AND METHODS}

One hundred and forty seven households having migrant family member (at least one) were selected in Lekhnath Municipality of Kaski District, Nepal. The sampling procedure was purposive because of the unavailability of the list of remittance receiving households in the study area. The primary tool of data collection was direct interview with migrant people's household using questionnaire schedule. In this study descriptive and inferential statistics were used for presenting and analyzing the collected data. Paired t-test was applied to analyze the significance difference between average expenditure in different headings before and after migration.

\section{RESULTS AND DISCUSSION}

This is a descriptive study designed to measure the empowerment level of the female teachers and factors affecting it. Based on the information gathered from one hundred and forty seven respondents, we have the following results and discussion:

\subsection{Social Impact of Remittance}

Several variables were included in the survey in order to examine the social impact of remittance on the labour sending households. The focus was on participation in community activities, children's education, and use of health services.

\subsubsection{Community participation}

Community participation is one of the social capitals for a person to know the society. In this study, organization was counted as mother's group, school management committee members, community forest management committee members, youth club members and cooperatives members. 
Table 1: Post of Organization by Participation in Community Program

\begin{tabular}{lllllll}
\hline Position held & \multicolumn{3}{c}{ Participation in Community Program } & \multicolumn{2}{c}{ Total } \\
\cline { 2 - 6 } & \multicolumn{2}{c}{ Yes } & \multicolumn{2}{c}{ No } & \\
\cline { 2 - 6 } & Number & Percentage & Number & Percentage & Number & Percentage \\
\hline Committee member & 18 & 14.2 & 5 & 62.5 & 23 & 17.0 \\
Executive member & 16 & 12.6 & 1 & 12.5 & 17 & 12.6 \\
General member & 93 & 73.2 & 2 & 25.0 & 95 & 70.4 \\
Total & 127 & 100 & 8 & 100 & 135 & 100.0 \\
\hline
\end{tabular}

Source: Field Survey, 2013

Table 1 shows the post of organization and participation in community program. Among 147 household 135 households members were involved in some types of organization. Among them majority $(70.4 \%)$ of the household members were general member of that organization. Nearly 17 percent of households members were committee member and 12.6 percent of household members were executive committee members.

\subsubsection{Educational institutions and distance}

Children education was examined in different ways; the first age of schooling, the proportion of children time to reach their school. In Nepal, children begin formal education at 5 years of age and generally complete their primary education by 9 years of age. Middle and secondary level of education should be completed by the time children are 15 years of age, which means they have had 10 years of schooling.

Table 2: Children School before and after Migration

\begin{tabular}{lcccc}
\hline \multirow{2}{*}{$\begin{array}{l}\text { Type of children's } \\
\text { school }\end{array}$} & \multicolumn{2}{c}{ Before migration } & \multicolumn{2}{c}{ After migration } \\
\cline { 2 - 5 } & Number & Percentage & Number & Percentage \\
\hline Government and other & 57 & 38.8 & 48 & 32.7 \\
Public private partnership & 8 & 5.4 & 23 & 15.6 \\
Private & 82 & 55.8 & 76 & 51.7 \\
Total & 147 & 100.0 & 147 & 100.0 \\
\hline
\end{tabular}

Source: Field survey, 2013

Table 2 shows the children school before and after migration. Less than two third of the household children studied in private schools and 5.4 percent children studied at public private partnership schools before migration. These trends were similar after migration. Majority of the children school were private school $(51.7 \%)$ and less (15.6\%) public private partnership school after migration. Therefore, after migration public private partnership schooling was increasing. 
Table 3: Remittance Received in a Year by Children School

\begin{tabular}{|c|c|c|c|c|c|c|c|c|}
\hline \multirow{3}{*}{$\begin{array}{l}\text { Total Remittance } \\
\text { Received in a Year } \\
\text { (Rs) }\end{array}$} & \multicolumn{6}{|c|}{ Children School } & \multicolumn{2}{|c|}{ Total } \\
\hline & \multicolumn{2}{|c|}{$\begin{array}{l}\text { Government and } \\
\text { other }\end{array}$} & \multicolumn{2}{|c|}{$\begin{array}{l}\text { Public private } \\
\text { partnership }\end{array}$} & \multicolumn{2}{|c|}{ Private } & \multirow[b]{2}{*}{$\mathrm{N}$} & \multirow[b]{2}{*}{$\%$} \\
\hline & $\mathrm{N}$ & $\%$ & $\mathrm{~N}$ & $\%$ & $\mathrm{~N}$ & $\%$ & & \\
\hline Below 2 Lakh & 14 & 9.5 & 5 & 3.4 & 7 & 4.8 & 26 & 17.7 \\
\hline 2 Lakh-4 Lakh & 25 & 17.0 & 13 & 8.8 & 34 & 23.1 & 72 & 49.0 \\
\hline 4 Lakh -6 Lakh & 6 & 4.1 & 2 & 1.4 & 15 & 10.2 & 23 & 15.6 \\
\hline 6 Lakh and above & 3 & 2.0 & 3 & 2.0 & 20 & 13.6 & 26 & 17.7 \\
\hline Total & 48 & 32.7 & 23 & 15.6 & 76 & 51.7 & 147 & 100.0 \\
\hline
\end{tabular}

Source: Field survey, 2013

Table 3 shows remittance received in a year and children schooling in the households. Schooling system is categorized as government school, public private partnership and private schooling. Majority $(51.7 \%)$ of the children were studying in private school which is followed by government and other $(32.7 \%)$ schooling. Minimum percentage of the households children were studying public private partnership school (15.6\%).

Table 4: Time to Reach School before and after Migration

\begin{tabular}{lcccc}
\hline \multirow{2}{*}{$\begin{array}{l}\text { Time to reach school (in } \\
\text { minutes) }\end{array}$} & \multicolumn{2}{c}{ Before migration } & \multicolumn{2}{c}{ After migration } \\
\cline { 2 - 5 } & Number & Percentage & Number & Percentage \\
\hline 45 and above & 48 & 32.7 & 47 & 32.0 \\
15 to 30 & 54 & 36.7 & 48 & 32.7 \\
15 and below & 45 & 30.6 & 52 & 35.4 \\
Total & 147 & 100.0 & 147 & 100.0 \\
\hline
\end{tabular}

Source: Field survey, 2013

Table 4 shows the time to reach school before and after migration. More than one third of the household children used to reached their school between (15 to 30) minute and 30.6 percent of households children reach their school within 15 minute of time before migration. The households children reached their school within 15 minutes of time (35.4\%) and 32.7 percent of household children reached their educational institution between 15 to 30 minute time after migration. This trend shows that migration increases the access to educational institution near at home.

Table 5: Remittances Received in a Year by Time to Reach School

\begin{tabular}{|c|c|c|c|c|c|c|c|c|}
\hline \multirow{3}{*}{$\begin{array}{l}\text { Total remittance } \\
\text { received in a year (in } \\
\text { lakh Rs.) }\end{array}$} & \multicolumn{6}{|c|}{ Time to reach school (in minute) } & \multirow{2}{*}{\multicolumn{2}{|c|}{ Total }} \\
\hline & \multicolumn{2}{|c|}{45 and above } & \multicolumn{2}{|c|}{15 to 30} & \multicolumn{2}{|c|}{ Below 15} & & \\
\hline & $\mathrm{N}$ & $\%$ & $\mathrm{~N}$ & $\%$ & $\mathrm{~N}$ & $\%$ & $\mathrm{~N}$ & $\%$ \\
\hline Below 2 & 7 & 4.8 & 14 & 9.5 & 5 & 3.4 & 26 & 17.7 \\
\hline $2-4$ & 30 & 20.4 & 22 & 15.0 & 20 & 13.6 & 72 & 49.0 \\
\hline $4-6$ & 4 & 2.7 & 4 & 2.7 & 15 & 10.2 & 23 & 15.6 \\
\hline 6 and above & 6 & 4.1 & 8 & 5.4 & 12 & 8.2 & 26 & 17.7 \\
\hline Total & 47 & 32.0 & 48 & 32.7 & 52 & 35.4 & 147 & 100 \\
\hline
\end{tabular}


Table 5 shows the remittance received in a year and time to reach school to the children. Majority (35.4\%) of the households children spent fifteen and below minutes of time to reach their educational institution which is higher in medium range of remittance (Rs. 2 Lakh- Rs. 4 Lakh) receiving households. This trend shows that majority of the migrant households are nearer to the educational institution. Nearly equal $(32.7 \%, 32 \%)$ percentage of households are far from above fifteen minute. Therefore, if members of households have migrated then other family member also migrate toward better facilitated areas of Nepal. So, both variables are associated with each other. The government of Nepal has endorsed the Millennium Development Goals; including the achievement of universal primary education by 2015. Schooling system is one of the most important basic necessities for the society. If the households, economically well are offered better schooling than other. So, income of the households is major affecting factor for the development in society as well.

\subsection{Health Status}

Remittance can lead to the improvement in health status in mainly two ways; first they can be used to improve the nutritional status of the population, particularly children, through the provision of good quality food; second, this money can be used to access better health services in the case of illness. Family planning service is major reproductive issues of Nepal. Population growth rate is higher in Nepal because of the unavailability of family planning services. Geographic diversity is one of the major challenges for state intervention. Table 6 shows the health variable recorded in survey time.

Table 6: State of Health Variables

\begin{tabular}{lcc}
\hline Health Variables & Number & Percentage \\
\hline Delivery Attendance & & \\
$\quad$ House (Without CHW*) & 34 & 23.1 \\
House (With CHW*) & 63 & 42.9 \\
Hospital & 50 & 34.0 \\
Family Planning & & \\
$\quad$ No & 75 & 51.0 \\
$\quad$ Yes & 72 & 49.0 \\
Antenatal Health Checkup & & \\
$\quad$ No & 46 & 31.3 \\
Yes & 101 & 68.7 \\
Water Purification & & \\
$\quad$ Filtered & 58 & 39.5 \\
$\quad$ Not purified & 54 & 36.7 \\
$\quad$ Boiled & 34 & 23.1 \\
$\quad$ Sodish and other & 1 & 0.7 \\
Know about Reproductive Health & & \\
$\quad$ No & 72 & 49.0 \\
$\quad$ Yes & 75 & 51.0 \\
Total & 147 & 100 \\
\hline
\end{tabular}

Source: Field survey, 2013

*CHW= Community Health Worker 
More than one third of the household members were given birth to their children with the help of community health worker. Proportion of household members $(34 \%)$ who gave birth their children in hospital is also existed in the study area. Nearly equal percentage (51and 49) of household members was found family planned and non family planned respectively. More than two third $(68.7 \%)$ of the household members were antenatal health checked and 31.3 percent household members were not antenatal health checked. More than one third (39.5\%) households were drinking filtered water which is followed by 36.7 percent of drinking non purified water. Around 23 percent of households were drink boiled water and 0.7 percent of households sodish and other types. Nearly equal proportion of the household members had knowledge about reproductive health.

\subsection{Economic Impact of Remittance on Receiving Households}

Households with their family members working overseas were to improved their economic status and social status through the flow of remittances. In addition to the analysis on investments provided in the previous section, this improvement can be examined in several ways. This section focuses on three dimensions: households amenities before and after migrant household uses; food sufficiency and use of new technology; and expenditure in households.

\subsubsection{Household amenities before and after migrant household uses}

Migrant household economic status is very much well compared to non-migrant household because of regular source of income. Economic status should be measured as household amenities they use in their household. In this study purpose twelve types of household amenities were recorded before migration and after migration households they uses.

Table 7: Household Amenities before and after Migrant Household's Uses

\begin{tabular}{lcccc}
\hline \multirow{2}{*}{ Household Amenities } & \multicolumn{4}{c}{ Responses } \\
\cline { 2 - 5 } & \multicolumn{3}{c}{ Before } & \multicolumn{3}{c}{ After } \\
\cline { 2 - 5 } & Number & Percentage & Number & Percentage \\
\hline Radio & 129 & 33.2 & 118 & 14.9 \\
Television & 60 & 15.4 & 139 & 17.6 \\
Mobile phone & 57 & 14.7 & 139 & 17.6 \\
Bio-gas/ L.P. gas & 56 & 14.4 & 123 & 15.5 \\
Cycle & 24 & 6.2 & 32 & 4.0 \\
Cable television & 23 & 5.9 & 90 & 11.4 \\
Refrigerator & 12 & 3.1 & 32 & 4.0 \\
Telephone & 10 & 2.6 & 17 & 2.1 \\
Motorcycle & 7 & 1.8 & 24 & 3.0 \\
Computer & 6 & 1.5 & 49 & 6.2 \\
Internet & 3 & 0.8 & 25 & 3.2 \\
Motor & 2 & 0.5 & 4 & 0.5 \\
Based on total 389 responses & & & Based on total 792 responses \\
\hline
\end{tabular}

Source: Field Survey, 2013

Table 7 shows the household amenities before and after migration. One third of the households were use radio as a household amenity which was followed by television (15.4\%) before 
migration. Less number $(0.5 \%)$ of households used motor as their amenity both before and after migration. In that case 17.6 percent of households used mobile phone and television after migration.

\subsubsection{Food sufficiency and use of new technology}

Agriculture is one of the major occupations of the Nepalese households. But their own production is subsistence in nature and their own production could not enough for a year. So, majority of the households of Nepal are dependent on buying foods in other areas.

Table 8: Total Remittances Received in a Year by Food Sufficiency

\begin{tabular}{|c|c|c|c|c|c|c|}
\hline \multirow{3}{*}{$\begin{array}{l}\text { Total remittance received } \\
\text { in a year }\end{array}$} & \multicolumn{4}{|c|}{ Food sufficiency in their own production } & \multirow{2}{*}{\multicolumn{2}{|c|}{ Total }} \\
\hline & \multicolumn{2}{|c|}{ No } & \multicolumn{2}{|c|}{ Yes } & & \\
\hline & $\mathrm{N}$ & $\%$ & $\mathrm{~N}$ & $\%$ & $\mathrm{~N}$ & $\%$ \\
\hline Below Rs. 2 Lakh & 9 & 6.1 & 17 & 11.6 & 26 & 17.7 \\
\hline Rs. 2 Lakh -4 Lakh & 27 & 18.4 & 45 & 30.6 & 72 & 49.0 \\
\hline Rs.4 Lakh -6 Lakh & 10 & 6.8 & 13 & 8.8 & 23 & 15.6 \\
\hline Rs. 6 Lakh and above & 12 & 8.2 & 14 & 9.5 & 26 & 17.7 \\
\hline Total & 58 & 39.5 & 89 & 60.5 & 147 & 100.0 \\
\hline
\end{tabular}

Source: Field Survey, 2013

Table 8 shows the total remittance received in a year by food sufficiency in their own production. Less than two third of the households had food sufficiency in their own production compared to (39.5\%) of the household haves non sufficiency food production. Higher food sufficiency is found among Rs. (2 Lakh -4 Lakh) in remittance received group as compared to other groups.

Foreign employment is one of the major livelihood strategies for Nepal. Majority of the land is owned by high class feudal but grassroots civil are deprived of owning land for sufficient food production. Hence, migrant households have less land occupancy than other non-migrant household. In that case, costs of migration have been paid by selling their property.

Table 9: Land Occupancy and Dependent in Foreign Employment for Food after Migration

\begin{tabular}{|c|c|c|c|c|c|c|}
\hline \multirow{3}{*}{$\begin{array}{l}\text { After migration land } \\
\text { occupancy }\end{array}$} & \multicolumn{4}{|c|}{ Dependent in foreign employment for food } & & \\
\hline & \multicolumn{2}{|c|}{ Yes } & \multicolumn{2}{|c|}{ No } & \multicolumn{2}{|c|}{ Total } \\
\hline & $\mathrm{N}$ & $\%$ & $\mathrm{~N}$ & $\%$ & $\mathrm{~N}$ & $\%$ \\
\hline As same & 48 & 32.7 & 56 & 38.1 & 104 & 70.7 \\
\hline Decrease in land & 14 & 9.5 & 9 & 6.1 & 23 & 15.6 \\
\hline Increase in land & 9 & 6.1 & 11 & 7.5 & 20 & 13.6 \\
\hline Total & 71 & 48.3 & 76 & 51.7 & 147 & 100.0 \\
\hline
\end{tabular}

Source: Field survey, 2013

Table 9 shows the land occupancy after migration and dependence in foreign employment for food. The entire migrant households are not economically well even after migration it is such because of their employment opportunity at destination country. This study proves that majority of 
the households owned same quantity of land occupancy after migration. Nearly 16 percent of households were with decrease in land occupancy after migration and 13.6 percent of households were with increase land occupancy after migration. In that case majority $(51.7 \%)$ of the households were not dependent on foreign employment for food which is compared to 48.4 percent of household dependency on foreign employment for food. Land increased households $(6.1 \%)$ were dependent on foreign employment for food.

Industrialization and globalization affect each and every country of the world. Naturally, Nepal is not the exception to this. Modern types of technology were used in each and every households of Nepal because of its easy access. Purchasing power of the nation is increasing regularly because of the availability of job in the private sector, migration and increasing the charge of labour.

Table 10: Total Remittance Received in a Year by Use of New Technology

\begin{tabular}{|c|c|c|c|c|c|c|}
\hline \multirow{3}{*}{$\begin{array}{l}\text { Total remittance } \\
\text { received in a year }\end{array}$} & \multicolumn{4}{|c|}{ Use of new technology } & & \\
\hline & \multicolumn{2}{|c|}{ Yes } & \multicolumn{2}{|c|}{ No } & \multicolumn{2}{|c|}{ Total } \\
\hline & $\mathrm{N}$ & $\%$ & $\mathrm{~N}$ & $\%$ & $\mathrm{~N}$ & $\%$ \\
\hline Below Rs. 2 Lakh & 16 & 10.9 & 10 & 6.8 & 26 & 17.7 \\
\hline Rs. 2 Lakh -4 Lakh & 69 & 46.9 & 3 & 2.0 & 72 & 49.0 \\
\hline Rs. 4 Lakh -6 Lakh & 23 & 15.6 & 0 & 0.0 & 23 & 15.6 \\
\hline Rs. 6 Lakh and above & 25 & 17.0 & 1 & 0.7 & 26 & 17.7 \\
\hline Total & 133 & 90.5 & 14 & 9.5 & 147 & 100 \\
\hline
\end{tabular}

Source: Field survey, 2013

Note: New technology: Fan, T.V, Mobile phone, Rice cooker, Mixture, Sound system, Telephone set, L.P. Gas, Refrigerator, Vacuum cleaner, Micro oven, Washing machine.

Table 10 shows the total remittance received in a year and use of new Technology. Most of the households used new technology at home, among them it was higher in remittance receiving group Rs. 2 Lakh-4 Lakh. This proportion was lower in remittance receiving group below Rs. 2 Lakh. Food is one of the most necessary daily consumptions of every household. Majority of the household occupants are agricultural. Table 10 shows the food sufficiency condition of the household before household member was migrated.

Table 11: Food Sufficient by Own Production Before and After Migration

\begin{tabular}{lcccc}
\hline Food sufficiency status & \multicolumn{2}{c}{ Before migration } & \multicolumn{2}{c}{ After migration } \\
\cline { 2 - 5 } & $\mathrm{N}$ & $\%$ & $\mathrm{~N}$ & $\%$ \\
\hline Yes & 61 & 41.5 & 58 & 39.5 \\
No & 86 & 58.5 & 89 & 60.5 \\
Total & 147 & 100 & 147 & 100 \\
\hline
\end{tabular}

Source: Field survey, 2013

There is no any vast difference in food sufficiency before and after migration. Majority (41.5\%) of the households were sufficient in food in their own production before migration. These trends 
were slightly different 39.5 percent of the migrant households having food sufficiency to their own production after migration.

\subsubsection{Household's expenditure}

Remittance increases the income of the households. The low level of income could not reach the basic basket of goods but if the income level increases then ability to purchase luxury goods also increases. So, remittance increases the expenditure behavior of the people. Table 4.23 shows remittances increase the expenditure in household exactly.

Table 12: Household Expenditure Before and After Migration

\begin{tabular}{lll}
\hline S. N & Paired variable (before and after) & $*$ P- value \\
\hline 1. & Educational expenditure in (Rs) & $0.00^{*}$ \\
2. & Health expenditure (Rs) & $0.00^{*}$ \\
3. & Transportation expenditure (Rs) & $0.00^{*}$ \\
4. & Communication expenditure (Rs) & $0.00^{*}$ \\
5. & Living arrangement expenditure (Rs) & $0.02 * *$ \\
6. & Clothing expenditure (Rs) & $0.00^{*}$ \\
7. & Total family expenditure (Rs) & $0.00^{*}$ \\
\hline
\end{tabular}

Source: Field survey, 2013

Note: *p-value is significant at 1\% level of significance

**p-value is significance at $5 \%$ level of significant (based on paired t-test)

Table 12 shows the significant difference between expenditure on seven different variables before and after migration. Expenditure on education, health, transportation, communication, clothing and total family expenditure before and after migration is significant at 1 percent level of significance $(\mathrm{p}<0.01)$. Similarly, living arrangement expenditure before and after migration is significant at $5 \%$ level of significance $(\mathrm{p}<0.05)$. These trends show that remittance increases the expenditure of households on consumption.

\section{CONCLUSION}

Remittance is one of the major income sources of earning foreign currency in Nepal. It really affects the income level of the households as well as society. This study analyzes the socioeconomic impact of remittance on households expenditure. Overall finding suggests that remittance helps particularly in escaping poverty and increasing overall economic status of the migrants and their households, and improving the ability of the households to increase expenditure. One could argue, however, that such an increase in expenditure cerates dependency because the migrants have to continue living abroad in order to maintain their livelihood. There are many success stories of investment made from remittances having lasting effects on the economic status of the households. The social contribution of migration is even more encouraging in terms of improving children's education and enhancing the overall social status of the households. 


\section{REFERENCES}

Adams, Jr. R. (2006). WB: Remittances, household expenditure and investment in Guatemala. Policy Research Working Paper No. 3532. Washington DC.

Alishani, A. and Nushi, A. (2012). Migration and development: The effects of remittance on education and health of family member left behind for the case of Kosovo. Analytical Journal, 5(1), 42-57.

Arif, G., M. (2009). Economic and social impacts of remittances on households: The case of Pakistani migrants working in Saudi Arabia. Islamabad: Pakistan Institute of Development Economics.

CBS. (2011). Statistical Pocket Book. Kathmandu: Center Bureau of Statistics.

Dahal, M. K. (Ed.). (2004). Nepalese economy: Towards building a strong economic nation state. Kathmandu: New Hira Books Enterprises.

Nair, R. P. (2009). The impacts of gender and remittance on household's expenditure pattern in Nepal. Unpublished Graduate Thesis, Graduate school of arts and science, Washington, DC.

Taylor, E. (1999). The new economics of labour migration and the role of remittance in the migration process. International migration quarterly Review, 37(1), 63-88.

Yusufi, I. (2012). Migration from the prospective of sending country: The literature and the facts. Analytical Journal, 5(10), 20-41. 